\title{
Garden Fleahopper, Halticus bractatus (Say) $)^{1}$
}

John L. Capinera ${ }^{2}$

\section{Introduction}

The garden fleahopper is a native insect occurring widely in the eastern United States and Canada. It is known to occur as far west as the Rocky Mountain region, but is relatively uncommon in the Great Plains. Its distribution extends southward through Central and South America to Argentina. In Florida it is a common garden pest, though not commonly a pest of commercial crops.

\section{Description and Life Cycle}

There appears to be five generations annually in Virginia, although there is considerable overlap among the generations, and all stages can be found through the warmer months. A life cycle can be completed in about 30 days. Overwintering occurs in the egg stage, with hatch of overwintering eggs occurring in April. In Florida, fleahoppers are present earlier in the season, and it has not been determined whether eggs hatch earlier or whether adults are the predominant overwintering form. However, adults have been captured all months of the year except December, so overwintering of eggs is not essential under Florida's warm winter conditions.
Temperatures above $32^{\circ} \mathrm{C}$ are reported to be unsuitable for fleahopper survival.

\section{Egg}

The eggs are normally inserted into the stems of vegetation. They are white to yellow in color, and measure about $0.7 \mathrm{~mm}$ in length and $0.2 \mathrm{~mm}$ in width. The egg is curved in shape, with one side convex and the opposite side concave. The female deposits the eggs in feeding punctures. The end inserted into the plant tissue is rounded whereas the end that is flush with the plant surface is truncate and level with the surface of the plant tissue. The female commences egg production about four days after mating, and deposits most eggs during the evening hours. She produces 80 to 100 eggs during her life span, which averages about 30 to 50 days. Duration of the egg stage is about 14 days, with a range of about 10 to 30 days.

\section{Nymph}

The nymphs are green in color. Initially they are pale green, but by the fifth and final instar they are dark green. First and second instars are difficult to distinguish, differing principally in size. In the third

1. This document is EENY-078, one of a series of Featured Creatures from the Entomology and Nematology Department, Florida Cooperative Extension Service, Institute of Food and Agricultural Sciences, University of Florida. Published: March 1999. Revised: October 2001. This document is also available on Featured Creatures Website at http://creatures.ifas.ufl.edu. Please visit the EDIS Website at http://edis.ifas.ufl.edu. Additional information on these organisms, including many color photographs, is available at the Entomology and Nematology Department WWW site at http://entnemdept.ifas.ufl.edu/.

2. John L. Capinera, professor/department chairman, Department of Entomology and Nematology, Cooperative Extension Service, Institute of Food and Agricultural Sciences, University of Florida, Gaiensville, FL 32511.

The Institute of Food and Agricultural Sciences (IFAS) is an Equal Employment Opportunity - Affirmative Action Employer authorized to provide research, educational information and other services only to individuals and institutions that function without regard to race, creed, color, religion, age, disability, sex, sexual orientation, marital status, national origin, political opinions or affiliations. For information on obtaining other extension publications, contact your county Cooperative Extension Service office. Florida Cooperative Extension Service / Institute of Food and Agricultural Sciences / University of Florida / Larry R. Arrington, Interim Dean 


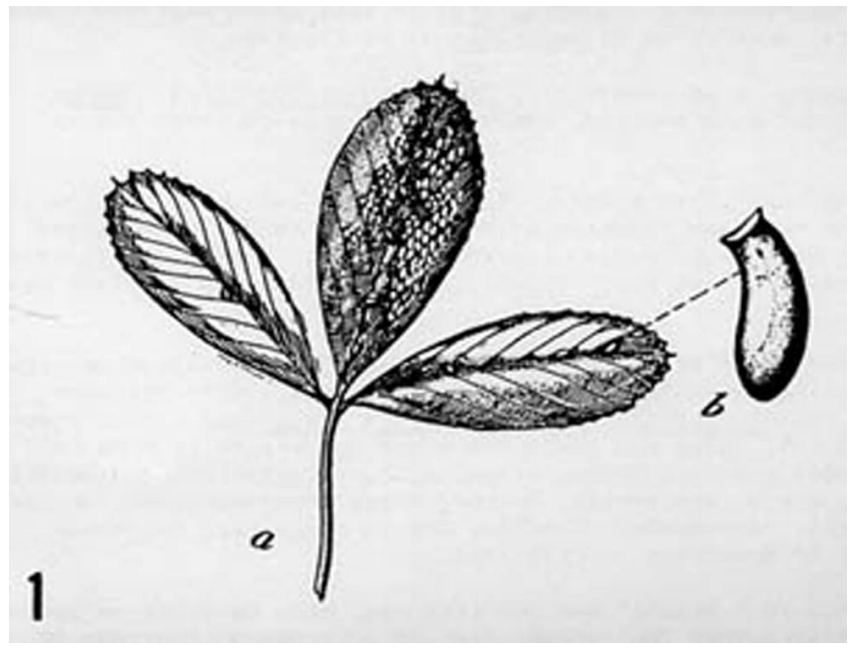

Figure 1. (a) Eggs on alfalfa leaf (b) egg

instar, however, a black dot is present on the sides of the prothoracic segment; the black spots persist through the remaining nymphal stages. In the fourth instar, wing pads are apparent, and extend back over the first abdominal segment. During the last instar the wingpads extend over about half of the abdominal segments. In females which are brachypterous (short-winged) as adults, the wings pads in the fifth instar tend to be slightly less than one-half the length of the abdomen. In males, or females which will be macropterous (long-winged) as adults, the wing pads in the fifth instar tend to be slightly longer than one-half the length of the abdomen. The mean duration of each instar is about 8.3, 9.9, 7.8, 5.8, and 7.2 days, respectively. Body length of each instar is about $0.7,0.8,1.0,1.2$, and $2.0 \mathrm{~mm}$, respectively.

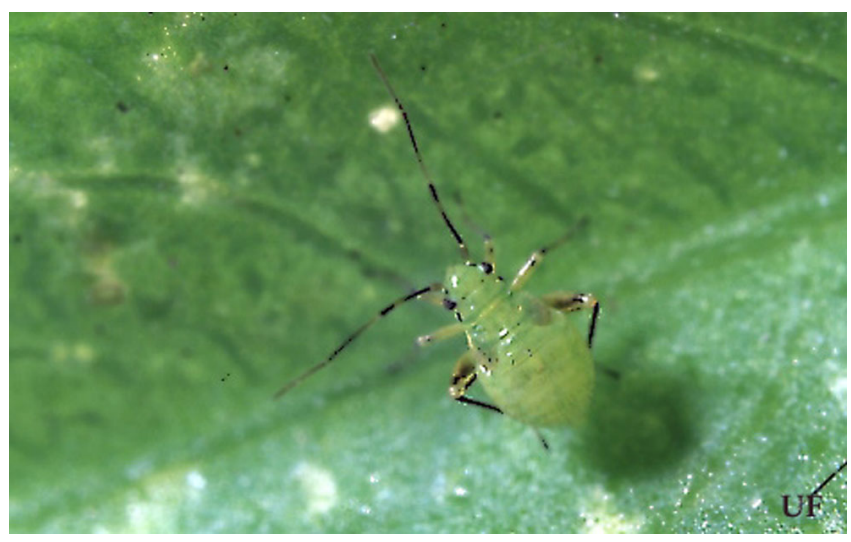

Figure 2. Nymph of garden fleahopper, Halticus bractatus (Say). Credits: Paul M. Choate, University of Florida

\section{Adult}

The adults are shiny black in color, with some yellow on the antennae and legs. Garden fleahopper adults occur in three forms: brachypterous (short-winged) females (Figure 3), macropterous (long-winged) females, and macropterous males (Figure 4). The males are thin, measuring about 1.9 to $2.1 \mathrm{~mm}$ in length and $0.7 \mathrm{~mm}$ in width. The females are more robust, the brachypterous form measuring about $1.6 \mathrm{~mm}$ in length and the macropterous form measuring about $2.2 \mathrm{~mm}$ in length, with both forms about $1.0 \mathrm{~mm}$ in width. Females generally are brachypterous. The adults have greatly expanded hind femora and hop when disturbed. Thus, in both behavior and form (especially the brachypterous females) the fleahoppers resemble flea beetles. The long antennae of fleahoppers exceed the length of the body; this helps to distinguish fleahoppers from flea beetles, which have antennae less than half the length of the body. Fleahoppers and flea beetles also differ in their mouthpart configuration, having piercing-sucking and chewing mouthparts, respectively.

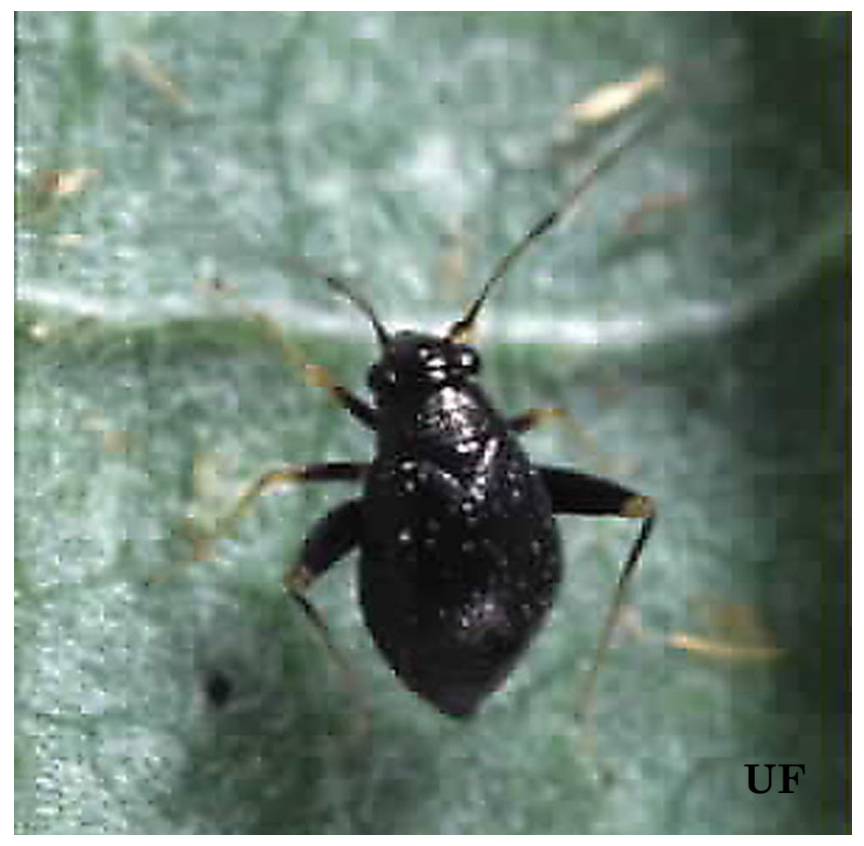

Figure 3. Brachypterous (short-winged) adult female garden fleahopper, Halticus bractatus (Say). Credits: Paul M. Choate, University of Florida 


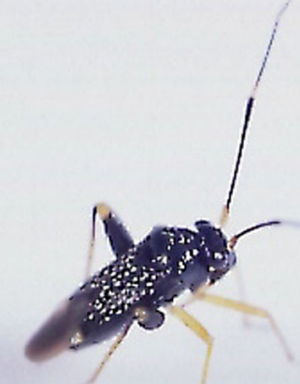

UF

Figure 4. Macropterous (long-winged) adult male garden fleahopper, Halticus bractatus (Say). Credits: Paul M. Choate, University of Florida

\section{Damage}

Nymphs and adults frequent the stems and surfaces of plant leaves, sucking the sap from individual cells and and causing their death. The result is a whitish or yellowish speckling on the foliage. Extensive feeding may cause stunting of plant growth and death of seedlings. Deposition of black spots of fecal material on the plant by both nymphs and adults also detracts from the appearance and marketability of vegetables.

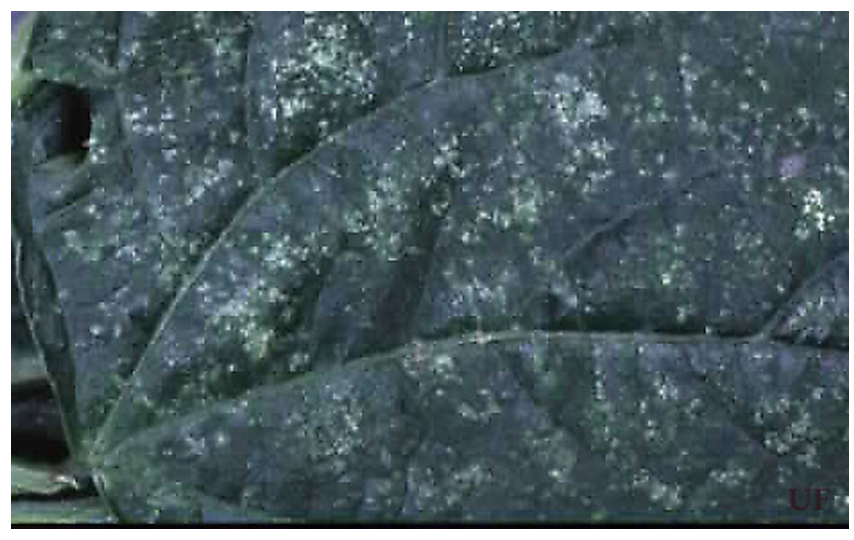

Figure 5. Leaf spotting caused by feeding of garden fleahopper, Halticus bractatus (Say). Credits: Paul M. Choate, University of Florida

This insect is rarely a pest of commercial vegetable crops because it is easily controlled with insecticides used against other, more serious, pests. However, it is commonly an early season nuisance in home gardens, especially those grown near wooded areas and on plants cultivated in semi-shade.

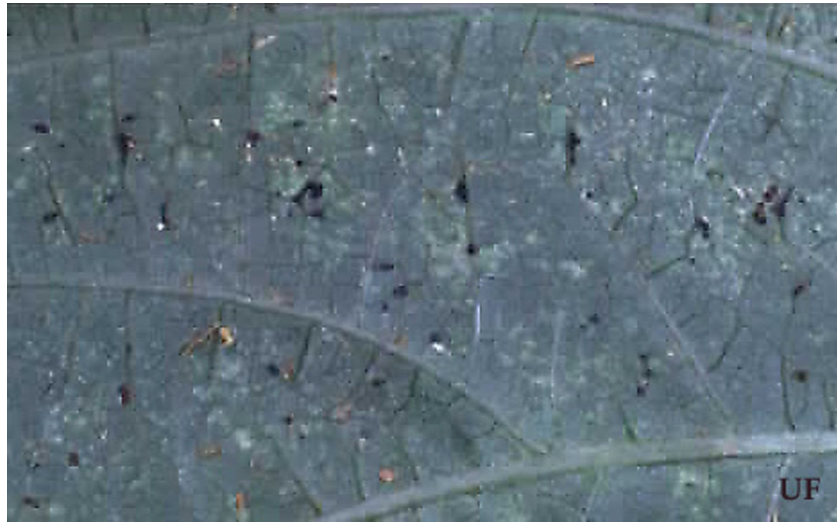

Figure 6. Fecal spots from the garden fleahopper, Halticus bractatus (Say), on underside of leaf. Credits: Paul M. Choate, University of Florida

\section{Host Plants}

This fleahopper has a broad host range, but leguminous crops are most frequently damaged. Vegetable crops that host garden fleahopper include bean, beet, cabbage, celery, cowpea, cucumber, eggplant, lettuce, pea, pepper, potato, pumpkin, squash, sweet potato, and tomato. Field crops injured include alfalfa, clover, and sweet clover. Some of the common weeds that support garden fleahopper are beggartick, Bidens sp.; bindweed, Convolvulus spp.; burdock, Arctium minus; mallow, Malva spp.; pigweed, Amaranthus spp.; plantain, Plantago spp.; ragweed, Ambrosia spp.; smartweed, Polygonum spp.; prickly lettuce, Lactuca serriola; thistle, Carduus spp.; and wood sorrel, Oxalis stricta. Occasionally it will feed on other insects.

\section{Natural Enemies}

Natural control has been poorly studied, but parasitic wasps can inflict high rates of mortality. In the United States, 50\% mortality caused by Leiophron uniformis (Gahan) (Hymenoptera: Braconidae) has been observed, and this parasitoid was believed to be regulating bug densities in New Jersey. L. uniformis attacks principally the nymphal stages. In Canada, Peristenus clematidis Loan (Hymenoptera: Braconidae) is known to parasitize garden fleahopper. An unidentified nematode and predatory mite also have been detected in the United States (Beyer 1921, Day and Saunders 1990). Beyer also reported several egg parasitoids, including Anaphes perdubius Girault and Anagrus sp. (both Hymenoptera: Mymaridae), and Oligosita americana 
Girault and Paracentrobia subflava Howard (both Hymenoptera: Trichogrammatidae).

\section{Management}

Suppression is easily accomplished with insecticides, including such botanical products as rotenone and sabadilla. Fleahoppers commonly frequent weeds, where they may attain great abundance, and such host plants should be monitored and sprayed or destroyed if necessary. Also, garden fleahopper sometimes builds to high number in leguminous crops such as alfalfa and clover, so nearby vegetables may be at risk when the leguminous forage crops are harvested.

For more information see:

Insect Management Guide for Vegetables (

http://edis.ifas.ufl.edu/

TOPIC_GUIDE_IG_Vegetables)

Insect Management Guide for Field Crops

(

http://edis.ifas.ufl.edu/

TOPIC_GUIDE_IG_Field_Crops_and_Pastures).

\section{Selected References}

Anonymous. (Unknown). Key to bugs. Insect and Related Pests of Flowers and Foliage Plants. http://www.mrec.ifas.ufl.edu/Foliage/entomol/ncstate/ bugskey.htm (30 October 2001).

Beyer, A.H. 1921. Garden flea-hopper in alfalfa and its control. USDA Bulletin 964. 27 pp.

Cagle, L.R. and H.W. Jackson. 1947. Life history of the garden fleahopper. Virginia Agricultural Experiment Station and Technical Bulletin 107. 27 pp.

Capinera, J.L. 2001. Handbook of Vegetable Pests. Academic Press, San Diego. 729pp.

Day, W.H. and L.B. Saunders. 1990. Abundance of the garden fleahopper (Hemiptera: Miridae) on alfalfa and parasitism by Leiophron uniformis (Gahan) (Hymenoptera: Braconidae). Journal of Economic Entomology 83:101-106. 